\title{
Influence of Planting Dates on Cane and Sugar Yields for Some Sugarcane Varieties
}

\author{
Mohamed Owais Ahmed Galal* and Ebaid Mustafa Mohamed Yousif \\ Sugar Crops Research Institute, Agricultural Research Center, Giza, Egypt
}

*Corresponding author: Mohamed Owais Ahmed Galal, Sugar Crops Research Institute, Agricultural Research Center, Giza, Egypt.

Received Date: June 16, 2019

Published Date: June 27, 2019

\begin{abstract}
The present study was carried out at El-Mattana Research Station, Luxor Governorate, Agricultural Research Center, Egypt. In two plant crop seasons of 2017/2018 and 2018/2019 to study the effect of planting dates on yield for three sugarcane varieties (G.T.54-9, G.98-28 and G.84-47) grown at three planting date in mid-March, mid-April and mid-May. The date of harvesting was in mid-March for all planting dates. A split plot arranged RCBD, in four replications, was used for the experiment. The three varieties were randomly distributed to the main plot while the three planting dates were assigned to sub-plot. The results indicated that planting sugarcane in mid-March was superior in millable cane/fed, cane weight, as well as cane and sugar yields in both seasons. The commercial sugarcane variety G.T.54-9 surpassed the other two varieties in the number of millable canes/ha, cane weight, as well as cane and sugar yields. However, the variance between the commercial sugarcane variety G.T.54-9 and G.84-47 in the studied traits was mostly insignificant. This indicates that reducing the growing season by delaying planting date reduced cane and sugar yields. Under conditions of this investigation, planting commercial sugarcane variety G.T.54-9 in mid-March can be recommended to obtain the highest cane and sugar yields/ha.
\end{abstract}

\section{Introduction}

The liberalization of Egypt's agricultural economic system led to major changes in farmers' behavior. Due to its limited water resources, the available area for farming is used in a rotation including more than one crop per year. The case is different in sugarcane growing area where the crop remains in soil for the whole year. A newly emerged problem is currently affecting spring planted crop. The growers intentionally delay sugarcane spring planting till the harvest of the preceding crop (broad bean or wheat) instead of growing temporary cover crop that can be cleared off the field in late February to plant sugarcane in March. As sugarcane growers are bound with contracts with the cane sugar company, they should start harvest of spring planted cane in a schedule that is prepared by the company. This causes a severe reduction in yield because of the decrease about three months in crop age. Many workers investigated the effect of decreasing growing season length on sugarcane yield. Jhansi \& Rao [1] pointed out that delaying the planting date led to reduction in cane yield. Dilip et al. [2] planted sugar cane cv. Co 419 on 15 March or 15 April. They found that mean cane yield was the highest $61.3 \mathrm{t} / \mathrm{ha}$ when sugar cane was planted on 15 March.
In Egypt, El-Gergawy \& El-Shafai [3] found that delaying planting date from March up to April resulted in a significant reduction in cane, and sugar yields. Later, Mohamed \& El-Taib [4] evaluated fourteen sugarcane genotypes plant crops under two planting dates (26 March and 26 April). They reported that, genotypes; and genotypes by growing seasons interaction; had significant effect on sugar recovery. Mohamed \& El-Taib [5] also reported that it is possible to maintain higher cane and sugar yield all over the milling season by selecting proper growing season for each genotype. However, reducing the growing season by delaying planting date reduced sugar yield as a result of reduction in cane yield throughout the reduction in number of millable cane. They also reported that the increase in sugar yield as a result of extending growing season by delaying harvesting did not compensate for the reduction resulted from late planting date. Okaz et al. [6] studied stability parameters of cane yield and its components for ten sugarcane genotypes under three planting dates (February 20, March 20 and April 20).Ten sugarcane genotypes were used, i.e. G 84-47, G 9519, G 95-21, G 98-24, G 98-28, G 99-103, G 99-165, Phil 8013, Mex 2001-80 and GT 54-9. The results indicated that the February 20th 
planting date was the best for sugarcane crop since it recorded the highest values for number of millable cane stalk weight and cane yield.

Many investigators found differences among the evaluated sugarcane varieties in their productivity and quality parameters [7-11].

The present study was aimed to evaluate the performance of two promising sugarcane varieties compared to commercial variety under different dates of planting to obtain the highest cane and sugar yields.

\section{Materials and Methods}

The present study was carried out at El-Mattana Research Station, Luxor Governorate, Agricultural Research Center, Egypt (Latitude $25^{\circ} 18^{\prime} \mathrm{N}$ ). Soil type of the experimental location was sandy loam with an average pH of 8.1, available $\mathrm{N}$ of $20 \mathrm{ppm}$, Available P of 11 ppm, and available K of 516 ppm. The work was conducted during the two plant crop seasons of 2017/2018 and $2018 / 2019$ to examine the effect of delayed planting date on yield on three sugarcane varieties (G.T.54-9, G.98-28 and G.84-47) grown at three planting date in mid-March, mid-April and mid-May. The date of harvesting was at mid-March for all planting dates.

Bartlett test of variance homogeneity was conducted on individual seasons data it revealed that single season analysis is feasible for this work than combined analysis. A split plot with four replications was used for the experiment as outlined by Gomez \& Gomez [12]. The three varieties were randomly distributed to the main plot. The three planting dates were assigned to the sub-plot. Sub-plot area was $42 \mathrm{~m} 2$. (comprised 6 ridges of $1 \mathrm{~m}$ apart and $7 \mathrm{~m}$ long). L.S.D. test was used for means comparisons.

\section{The Recorded Data}

At harvest (15th March in both seasons), a stalk sample was taken from a one-meter portion per plot to determine the mean values of stalk characteristics. In addition, four guarded rows of each plot were harvested, topped, and cleaned to estimate cane yield and supply the quality analysis sample per plot:

- Number of millable cane was counted per plot then converted into 1000/ha.

- $\quad$ Millable cane weight $(\mathrm{kg})$ was determined by dividing cane weight of the one-meter sample by its corresponding number of millable cane.

- $\quad$ Sugar recovery percentage was calculated according to Yadav and Sharma equation (1980) as follows:

- $\quad$ Sugar recovery $\%=[$ sucrose $\%-0.4$ (brix \% - sucrose \%) $\times 0.73]$,

- Where B = Brix reading, $\mathrm{S}=$ Sucrose percentage, 0.4 and 0.73 constants.

- $\quad$ Cane yield (tons/ha) was determined from the weight of the four middle guarded rows of each plot converted into value per ha.
- $\quad$ Sugar yield (tons/ha) was estimated by multiplying cane yield (tons $/$ ha) by sugar recovery $\%$.

\section{Results and Discussion}

\section{Number of millable canes/ha}

Data in Table 1 show that growing sugarcane in mid-March produced 6.64 and 21.63 thousand millable canes/ha higher than that grown in mid-April and mid-May, respectively, in the $1^{\text {st }}$ season, corresponding to 12.91 and 21.70 thousand millable canes/ha, in the $2^{\text {nd }}$ one. These results were in agreement with those reported by Okaz et al. [6].

The results indicated that G.T.54-9 sugarcane variety produced 14.97 and 13.30 thousand millable canes/ha higher than that obtained from G.98-28 and G.84-47, respectively, in the $1^{\text {st }}$ season, corresponding to 1.12 and 6.95 thousand millable canes/ha, in the $2^{\text {nd }}$ one. Varietals response could vary according to the dominated weather conditions during early parts of the growing season. It also indicated that varietal differences were marginal. Thus, the differences reported in the final count of millable cane could be attributed to different mortality rates of tillers based on the weather conditions and the genetic makeup of the tested varieties. Varietal differences in millable cane number were reported earlier by Shukla \& Singh [11] and Galal et al. [9].

Number of millable canes was significantly influenced by the interaction between the tested cane genotypes and planting methods in the $2^{\text {nd }}$ season only, where the difference between G.T.549 and G.98-28 in stalk length was insignificant when they were planted in mid-April and mid-May. However, G.T.54-9 surpassed G.98-28 in this trait when they were planted in mid-March.

\section{Stalk weight}

Data in Table 1 illustrated that stalk weight was largely affected by planting dates in the $1^{\text {st }}$ season only. Planting sugarcane in mid-March gave the highest stalk weight $(1.29 \mathrm{~kg})$ compared with planting sugarcane in mid-April and mid-May. The variation in weight per cane is attributed to variation in cane length attained during the crop growth period in different planting patterns. The results are in conformity with those of Mohamed \& El-Taib [5] and Okaz et al. [6].

The results cleared that G.T.45-9 commercial variety gave the highest stalk weight $(1.15$ and $1.31 \mathrm{~kg}$ in in both seasons, respectively) compared with the other varieties. However, the difference in stalk weight between the commercial variety G.T.549 and G.84-47 was insignificant, in the $1^{\text {st }}$ plant cane. The same finding was reported by Galal et al. [8].

Stalk weight $(\mathrm{kg})$ was significantly influenced by the interaction between the tested cane genotypes and planting dates in the $2^{\text {nd }}$ season only, where the difference between G.T.54-9 and G.84-47 in stalk weight was insignificant when they were planted in mid-May. However, the commercial variety G.T.54-9 surpassed G.84-47 in this trait when they were planted in mid-March and mid-April. 


\section{Sugar recovery percentage}

Sugar recovery \% was affected in a highly significant manner by planting dates in $2^{\text {nd }}$ season only.

Data in Table 1 revealed that early planting on March or April, despite of the planting date itself, had the highest percentage of sugar recovery in both seasons. As the length of the growing season increased, the recorded recovery percentages values increased. This is due to longer span where photosynthesis took place in March and April -planting as compared to May planting. Increasing sugar recovery due to longer growth season was observed by Mohamed \& El-Taib [4].

Table 1: Number of millable canes, stalk weight, sugar recovery percentages and cane and sugar yield/ha of the tested sugar cane varieties as affected by planting dates and their interactions, in 2017/2018 and 2018/2019.

\begin{tabular}{|c|c|c|c|c|c|c|c|c|c|c|c|}
\hline \multirow{2}{*}{\multicolumn{2}{|c|}{$\begin{array}{l}\text { Treat- } \\
\text { ments }\end{array}$}} & \multicolumn{2}{|c|}{$\begin{array}{l}\text { Number of Millable Canes } \\
(\mathbf{1 0 0 0 / h a )}\end{array}$} & \multicolumn{2}{|c|}{ Stalk Weight (g) } & \multicolumn{2}{|c|}{ Sugar Recovery\% } & \multicolumn{2}{|c|}{ Cane Yield (tons/ha) } & \multicolumn{2}{|c|}{$\begin{array}{l}\text { Sugar Yield } \\
\text { (tons/ha) }\end{array}$} \\
\hline & & 2017-2018 & 2018-2019 & 2017-2018 & 2018-2019 & 2017-2018 & 2018-2019 & 2017-2018 & $\begin{array}{l}2018- \\
2019\end{array}$ & $\begin{array}{l}2017- \\
2018\end{array}$ & $\begin{array}{r}2018- \\
2019\end{array}$ \\
\hline \multicolumn{12}{|c|}{ Planting Dates } \\
\hline \multicolumn{2}{|c|}{$* \mathrm{D} 1$} & 154.08 & 151.58 & 1.29 & 1.17 & 12 & 12.14 & 136.9 & 131.1 & 16.54 & 15.94 \\
\hline \multicolumn{2}{|c|}{$*$ D2 } & 147.44 & 138.66 & 0.96 & 1.12 & 11.59 & 12.08 & 101.1 & 102.3 & 11.81 & 12.38 \\
\hline \multicolumn{2}{|c|}{ *D3 } & 132.45 & 129.88 & 1.08 & 1.11 & 11.45 & 11.62 & 97.3 & 95.5 & 11.18 & 11.14 \\
\hline \multicolumn{2}{|c|}{$\begin{array}{l}\text { LSD at } 5 \% \\
\text { level }\end{array}$} & 9.21 & 10.14 & 0.08 & Ns & Ns & 0.27 & 4.9 & 5 & 0.97 & 0.61 \\
\hline \multicolumn{12}{|c|}{ Sugarcane Varieties } \\
\hline \multicolumn{2}{|c|}{$\begin{array}{l}\text { G.T.45-9 } \\
\text { (V1) }\end{array}$} & 154.08 & 142.73 & 1.15 & 1.31 & 12.8 & 12.39 & 124.2 & 118.3 & 15.92 & 14.68 \\
\hline \multicolumn{2}{|c|}{$\begin{array}{l}\text { G. } 84-47 \\
(V 2)\end{array}$} & 139.11 & 141.61 & 1.14 & 1.03 & 11.62 & 12.06 & 109.6 & 110.4 & 12.78 & 13.31 \\
\hline \multicolumn{2}{|c|}{$\begin{array}{l}\text { G. } 98-28 \\
\text { (V3) }\end{array}$} & 140.78 & 135.78 & 1.03 & 1.05 & 10.63 & 11.38 & 101.6 & 100.2 & 10.83 & 11.47 \\
\hline \multicolumn{2}{|c|}{$\begin{array}{l}\text { LSD at } 5 \% \\
\text { level }\end{array}$} & 8.09 & 5.83 & 0.05 & 0.1 & 0.44 & 0.43 & 3.2 & 3.2 & 0.58 & 0.54 \\
\hline \multicolumn{12}{|c|}{ Interaction } \\
\hline \multirow{3}{*}{ D1 } & V1 & 167.36 & 159.86 & 1.31 & 1.27 & 13.02 & 12.6 & 154.3 & 141.8 & 20.07 & 17.86 \\
\hline & $\mathrm{V} 2$ & 147.44 & 154.93 & 1.34 & 1.02 & 12.06 & 12.03 & 133.1 & 132 & 16.06 & 15.87 \\
\hline & V3 & 147.44 & 139.94 & 1.2 & 1.22 & 10.93 & 11.79 & 123.4 & 119.6 & 13.49 & 14.1 \\
\hline \multirow{3}{*}{$\mathrm{D} 2$} & $\mathrm{~V} 1$ & 154.93 & 138.6 & 0.99 & 1.33 & 13.28 & 12.55 & 110.3 & 110.2 & 14.63 & 13.83 \\
\hline & $\mathrm{V} 2$ & 144.94 & 129.95 & 0.96 & 1.1 & 11.08 & 12.02 & 99.3 & 99.8 & 11 & 11.99 \\
\hline & V3 & 142.44 & 147.44 & 0.94 & 0.94 & 10.42 & 11.67 & 93.9 & 96.9 & 9.79 & 11.31 \\
\hline \multirow{3}{*}{ D3 } & $\mathrm{V} 1$ & 139.94 & 129.75 & 1.15 & 1.34 & 12.1 & 12.03 & 108 & 102.8 & 13.05 & 12.35 \\
\hline & $\mathrm{V} 2$ & 139.94 & 129.75 & 1.15 & 1.34 & 12.1 & 12.03 & 108 & 102.8 & 13.05 & 12.35 \\
\hline & V3 & 132.45 & 119.95 & 0.95 & 1 & 10.54 & 10.69 & 87.6 & 84.2 & 9.2 & 9 \\
\hline \multicolumn{2}{|c|}{$\begin{array}{l}\text { LSD at } 5 \% \\
\quad \text { level }\end{array}$} & Ns & 10.11 & Ns & 0.17 & 0.76 & Ns & 5.6 & 5.5 & 1.01 & 0.94 \\
\hline
\end{tabular}

The results indicated that G.T.54-9 sugarcane variety produced 1.18 and $2.17 \%$ sugar recovery higher than that obtained from G.98-28 and G.84-47, respectively, in the $1^{\text {st }}$ season, corresponding to 0.33 and $1.01 \%$, in the $2^{\text {nd }}$ one. Moreover, it was found that the difference between G.T.54-9 and G.84-47 in this quality trait was insignificant in the $2^{\text {nd }}$ one. The difference among the evaluated sugarcane genotypes may be attributed to their genetic structure. The same findings were reported by Ahmed et al. [13] and Mehareb \& Galal [10].

Sugar recovery \% was significantly influenced by the interaction between the tested cane varieties and planting dates in the $1^{\text {st }}$ season only, where the difference between G.T.54-9 and G.84-47 in sugar recovery was insignificant when they were planted in midMay. However, the commercial variety G.T.54-9 surpassed G.84-47 in this trait when they were planted in mid-March and mid-April.

\section{Cane yield ton/ha}

Data in Table 1 show that growing sugarcane in mid-March produced 35.8 and 39.6 tons of canes higher than that grown in midApril and mid-May, respectively in the $1^{\text {st }}$ season, corresponding to 28.8 and 35.7 tons, in the $2^{\text {nd }}$ one. It is well established that longer growing season causes an increase in cane tonnage as reported by many workers Jhansi \& Rao [1] and Mohamed \& El-Taib [5].

The results in Table 1 showed G.T.54-9 produced 14.6 and 22.6 tons of cane higher than those gained by G. 84-47 or G. 98-28, respectively, in the $1^{\text {st }}$ season. In the $2^{\text {nd }}$ season, G.T.54-9 recorded 7.8 and 18.0 tons of canes over those given by the same two varieties, successively. The superiority of G.T.54-9 over the other two varieties is probably attributed to its highest values of number of millable canes per ha, stalk weight compared to the other two 
varieties. Such differences in varietal response are due to their variable interaction with environmental conditions. El-Sogheir \& Abd El Fattah [7] reported such observation on varietal yield differences.

Cane yield ton/ha was significantly influenced by the interaction between the tested cane varieties and planting dates in both seasons, where the difference between G.T.54-9 and G.84-47 in cane yield was insignificant when they were planted in mid-May. However, the commercial variety G.T.54-9 surpassed G.84-47 in this trait when they were planted in mid-March and mid-April.

\section{Sugar yield ton/ha}

Data in Table 1 show that sugar yield/ha was significantly affected by planting dates in both seasons. The results indicated that growing sugarcane in mid-March produced 4.7 and 5.4 tons of canes higher than that grown in mid-April and mid-May, respectively in the $1^{\text {st }}$ season, corresponding to 3.6 and 4.8 tons, in the $2^{\text {nd }}$ one. The same findings were reported by Dilip et al. [2], ElGergawy and El-Shafai [3] and Okaz et al. [6].

Means in Table 1 indicated that G.T.54-9 sugar production /ha was superior to the two other varieties in both seasons, where it produced 3.1 and 5.1 tons of sugar/ha higher than those given by G.84-47 and G.98-28, respectively, in the $1^{\text {st }}$ season, corresponding to 1.4 and 3.2 ton/ha, in the $2^{\text {nd }}$ one. Such increases are mainly due to the superiority of this variety in cane yield /ha as the three tested varieties were similar in theoretical sugar recovery $\%$ as shown in table. These results were in agreement with those reported by Shukla \& Singh [11] and Galal et al. [8].

Sugar yield tons/ha was significantly influenced by the interaction between the tested cane varieties and planting dates in both seasons, where the difference between G.T.54-9 and G.84-47 in sugar yield was insignificant when they were planted in mid-May. However, the commercial variety G.T.54-9 surpassed G.84-47 in this trait when they were planted in mid-March and mid-April [14].

\section{Conclusion}

Under conditions of this investigation, planting commercial sugarcane variety G.T.54-9 in mid-March can be recommended to obtain the highest cane and sugar yields/ha.

\section{Acknowledgement}

None.

\section{Conflict of Interest}

No conflict of interest.

\section{References}

1. Jhansi K, Rao BR (1996) Evaluation of promising varieties of sugar cane for shoot borer and internode borer under different dates of planting. Cooperative Sugar 27(9): 675-679.

2. Dilip S, Dhakar LL, Shaktawat MS, Singh D (1998) Effect of nursery and in situ planting of spring sugar cane (Saccharum officinarum L.) under variable date of sowing. Indian Sugar 48(9): 725-729.

3. El Gergawy ASS, El Shafai, AMA (2000) Yield and quality of some sugar cane varieties as affected by planting date. J Agric Sci Mansoura Univ 25(7): 3753-3760.

4. Mohamed BD, El Taib, ABA (2007a) Evaluation of some spring planted sugarcane genotypes under different growing seasons: 1- quality traits performance. Assiut J of Agri Sci 38(1): 1-15.

5. Mohamed BD, El Taib ABA (2007b) Evaluation of some spring planted sugar cane genotypes under different growing seasons: 2-Yield components, cane and sugar yield performance. Assiut J of Agri Sci 38(1): 17-29.

6. Okaz AM, BD Mohamed, SHM Abd El Haleem, EMM Yousif (2011) Stability parameters of cane yield and its components under various planting dates and interrow spacing for ten sugarcane genotypes (saccharum spp.). American-Eurasian J Agric \& Environ Sci 11(6): 929-937.

7. El Sogheir KS, Abd El Fattah AI (2009) Evaluation of some promising sugar cane varieties under different row spacing. J Biol Chem \& Environ Sci 4(1): 285-318.

8. Galal MOA, AM Abou Salama, EA Teama, AZ Ahmed (2015). Yield response of late planted spring sugarcane to direct set sowing and transplanting. Sci J King Faisal Univ (Basic Appl Sci) 16(1): 75-94.

9. Galal MOA, MAM Osman, AM Fahmy, A El Mohamed (2017) Performance of some sugarcane genotypes under different planting methods and natural infestation with insects and diseases. Egypt J Plant Breed 21(4):843-859.

10. Mehareb EM, MOA Galal (2017) Ratooning ability inheritance for some promising Egyptian sugarcane varieties. Indian J Sugarcane Technol 32(02): 50-59.

11. Shukla SK, I Singh (2011) Tillering pattern, growth and sugarcane yield of promising genotypes under different planting seasons and fertility levels in subtropical India. Indian J Sugarcane Technol 26(2): 10-13.

12. Gomez KA, Gomez AA (1984) Statistical Procedures for Agricultural Research. A Wiley-Inter-Science Publication, John Wiley and Sons, New York, pp. 1-690.

13. Ahmed ZA, AM Ahmed, MSH Osman (2011) Optimum inter-row spacing and number of ploughings for two promising sugarcane varieties. Egypt, J Agric Res 89(1): 301-316.

14. Yadav RL, RK Sharma (1980) Effect of nitrogen level and harvesting date on quality characteristics and yield of four sugar cane genotypes. Indian J Agric Sci 50(7): 581-589. 